\title{
微動測定に基づく地震前後における RC 造中低層建物の振動特性比較 COMPARISON OF DYNAMIC PROPERTIES OF LOW AND MID-RISE RC BUILDINGS BEFORE AND AFTER THE EARTHQUAKE BASED ON MICROTREMOR MEASUREMENT
}

\author{
鶴 村香 苗*, 川瀬＼cjkstart博** \\ Kanae TSURUMURA and Hiroshi KAWASE
}

\begin{abstract}
We analyzed dynamic characteristics of 79 low and mid-rise reinforced concrete (RC) buildings in Fukuoka City before and after the West off Fukuoka earthquake of 2005 obtained by microtremor measurement. Then we compared reduction ratios of stiffness with the input strong motion levels and the observed damage levels. The average of the stiffness reduction ratios of all data is 0.800 . As the values of the input strong motion level and the damage level become larger, the building stiffness deteriorates more. It is possible that the buildings that their stiffness deteriorates much larger than the average might be damaged in some invisible parts. The obtained results can be utilized as a standard reference for developments of damage detection methodology based on microtremor monitoring.
\end{abstract}

Keywords : microtremor, dynamic properties, resonant frequency, RC buildings, the West off Fukuoka earthquake 常時微動, 振動特性, 共振振動数, $\mathrm{RC}$ 造建物, 福岡県西方沖地震

\section{1.はじめに}

地震を経験した建物のうち、甚大な被害を避けられた建物におい てもその健全性を評価することは非常に重要である。外観上は被害 が認められず、健全であると判断された建物においても、目視が困 難な部位に損傷を受けている可能性があり、固有振動数が低下して いることが予想される。

兵庫県南部地震を機に、被災した建物がどの程度振動特性に影響 を受けたのかを常時微動に基づき実際の建物で評価した例が少なか らずある 1) 5)。それらの報告では、建物の損傷は固有振動数の顕著 な低下という形で現れることが明らかにされ、また構造部材そのも のに被害がない場合でも、非構造部材などの影響により固有振動数 にわずかな低下が見られることもあると指摘されている。このよう な実測による評価は極めて貴重なものである。しかしながら、これ らの測定は限られた特定の建物を対象としており、その評価結果は 限定的なものである。その原因の一つは、通常、地震前に建物の常 時微動測定が行われていることが少なく、実際の建物における測定 記録が蓄積されていないことにある。

多数の建物での実測の記録という観点からは、1978 年宮城県沖 の地震前後において、阿部ら 6)により仙台市内の 205 棟の建物で常 時微動測定が行われており、固有周期の変化について報告されてい
る。しかしながら、当時はそれぞれの建設地点での地震動レベルが 推定されておらず、得られた卓越周期の変化と入力地震動のレベル の関係については分析されていない。

そこで本論文では、1995 年に今岡ら 7)により行われていた福岡 市内の多数の建物の常時微動の測定結果、及び地震後に同一建物に 対して我々が実施した微動記録を用いて、2005 年福岡県西方沖地 震(M7.0)の前後における振動特性の変化を把握し、さらに、その変 化の程度と別途再現されている入力地震動レベルおよび地区別の建 物損傷度との比較を行い、それらの関係を評価する。

\section{2. 常時微動測定と波形解析 \\ 2. 1 測定建物}

対象建物は 1995 年に今岡ら 7)により常時微動測定が行われてい た建物のうち、4〜 14 階建の $\mathrm{RC}$ 造建物(7階建以上は $\mathrm{SRC}$ 造建 物を含む）の 79 棟で、福岡市中央区, 博多区, 南区，城南区，早 良区に立地する。表 1 に立地区・階数別の測定建物の内訳、図 1 に 震源と測定地域、写真 1 に測定建物の例を示す。

\section{2 測定方法}

今回の計測では、微動計は図 2 のように建物最上階 (一部は屋 上）と建物周辺地盤上（一部は建物最下階）に、地震前の測定資料 
表 1 測定建物棟数の内訳（立地区・階数別）

\begin{tabular}{|c|c|c|c|c|c|c|}
\hline 階数 \区 & 中央 & 博多 & 早良 & 南 & 域南 & 計 \\
\hline $4 \sim 6$ & 10 & 2 & 6 & 7 & 2 & 27 \\
\hline $7 \sim 9$ & 12 & 7 & 2 & 4 & 0 & 25 \\
\hline $10 \sim 14$ & 7 & 16 & 1 & 3 & 0 & 27 \\
\hline 計 & 29 & 25 & 9 & 14 & 2 & 79 \\
\hline
\end{tabular}

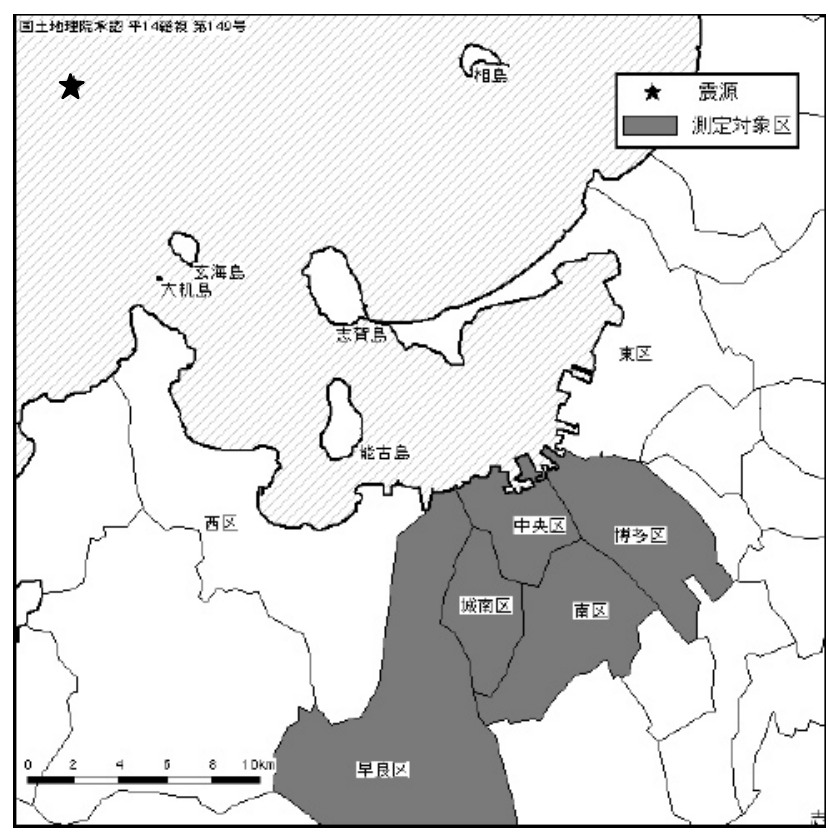

図 1 震源と測定地域

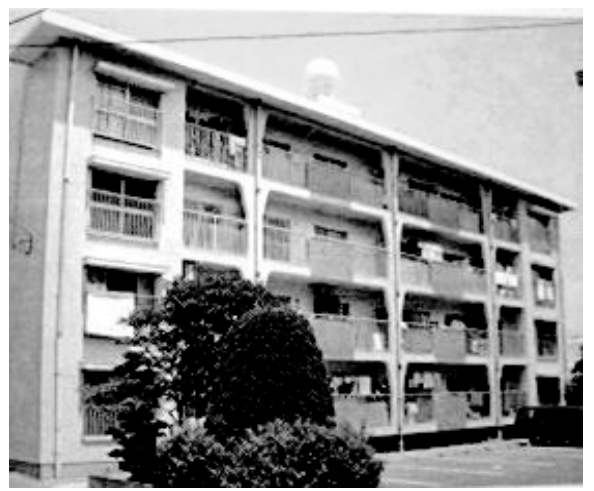

写真 1 測定建物の例

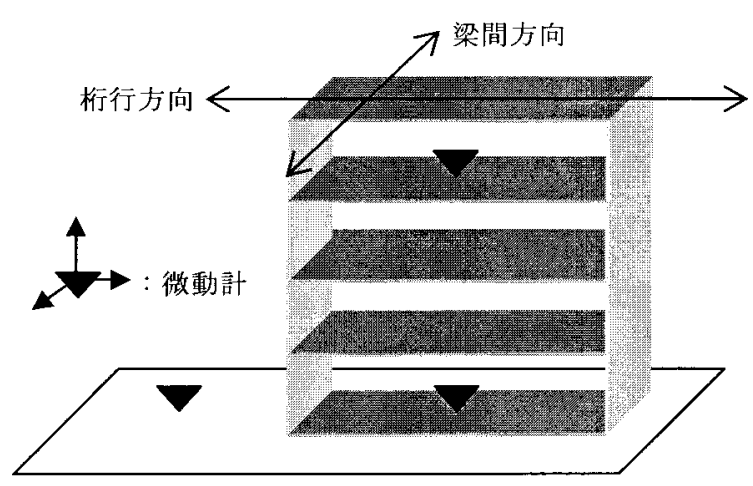

図 2 微動計設置例
を参考に当時と同じ位置に設置した。しかしながら、設置位置が不 明である場合や、当時と同じ位置に設置することが困難な場合には、 建物内では主要な構造柱の傍に、地盤上では建物周辺の駐車場や歩 道上に設置して測定を行った。周辺地盤上と建物最下階の置き換え については、建物と地盤の相互作用の影響が大きい場合には無視で きないが、今回の解析では誤差の範囲内として同様に扱うこととし た。その詳細については 2.4 節で述べる。

測定に用いた微動計は、0.1倍から 10，000倍のアンプ付き可搬 型の 3 成分加速度計アカシ SMAR-6A3P で、水平 2 成分（建物の短 辺・長辺）の変位波形を 15 分間 1 セットで記録した。ハイカット フィルター周波数を $50 \mathrm{~Hz}$ 、サンプリング周波数を $100 \mathrm{~Hz}$ とした。 時刻校正は GPS 時刻信号によって行い、各地点の同時性を確保し た。実施期間は、 2005 年 11 月、2006 年 8 月、 11 月で、雨天を避 け、昼間に行った。

\section{3 微動波形の解析方法}

本研究で実施した微動測定の波形処理では、地盤上（建物最下階） で得られた観測記録を $X_{i}$ 、建物最上階（屋上）で得られた測定記録 を $Y_{i}$ として解析を行った。まず FFTによって $i$ 番目の有限フーリ 工変換 $X_{i}(\omega), Y_{i}(\omega)$ を求める。これを用いて、解析に用いる $N$ 個のブロックのアンサンブル平均からパワースペクトル $S_{X X}(\omega)$, $S_{Y Y}(\omega)$ とクロススペクトル $S_{X Y}(\omega)$ を計算する。

$S_{X X}(\omega)=2 / N T \sum_{i=1}^{n}\left\{X_{i}(\omega) \cdot X_{i}^{*}(\omega)\right\}$

$S_{Y Y}(\omega)=2 / N T \sum_{i=1}^{n}\left\{Y_{i}(\omega) \cdot Y_{i}^{*}(\omega)\right\}$

$S_{X Y}(\omega)=2 / N T \sum_{i=1}^{n}\left\{Y_{i}(\omega) \cdot X_{i}^{*}(\omega)\right\}$

上付きの*は共役の複素数であることを示す。

上記のパワースペクトル、クロススペクトルから伝達関数 $H(\omega)$ 、 フェイズ関数 $\theta(\omega)$ 、コヒーレンス $\operatorname{coh}^{2}(\omega)$ 、スペクトル比 $R(\omega)$ を次式によって算定する。なお、伝達関数については、入出力ノイ ズの状態によって幾つかの算定式があるが、構造物については入力 側のノイズが少ない事を考慮して次の式を用いた。

$H(\omega)=\sqrt{S_{X Y}(\omega) / S_{X X}(\omega)}$

$\theta(\omega)=\tan ^{-1}\left\{\operatorname{Im}\left(S_{X Y}(\omega)\right) / \operatorname{Re}\left(S_{X Y}(\omega)\right)\right\}$

$\operatorname{coh}(\omega)^{2}=\left|S_{X Y}\right|^{2} /\left(S_{X X}(\omega) \cdot S_{Y Y}(\omega)\right)$

$R(\omega)=\sqrt{S_{Y Y}(\omega) / S_{X X}(\omega)}$

ここで、 $\operatorname{Im}($ （）Ｒ（）はそれぞれ虚部、実部を表している。

データ処理においては、まず微動測定から得られたデータを $50 \%$ オーバーラップさせて 40.96 秒の小区間に切り出す。そしてそのフ ーリエスペクトルおよびフーリエスペクトル比を求め、アンサンブ ル平均值を計算し、求めたフーリエスペクトル比の 1 次ピークを共 振振動数とし、建物の梁間方向と桁行方向のそれぞれについて読み 取る。この際ピークが明瞭でない場合には、フェイズが $0^{\circ}$ 付近か ら $180^{\circ}$ 近くまで急速に変化する振動数帯域の中で、90 9 付近の振 動数であることや、コヒーレンスの急激に低下寸る振動数であるこ 

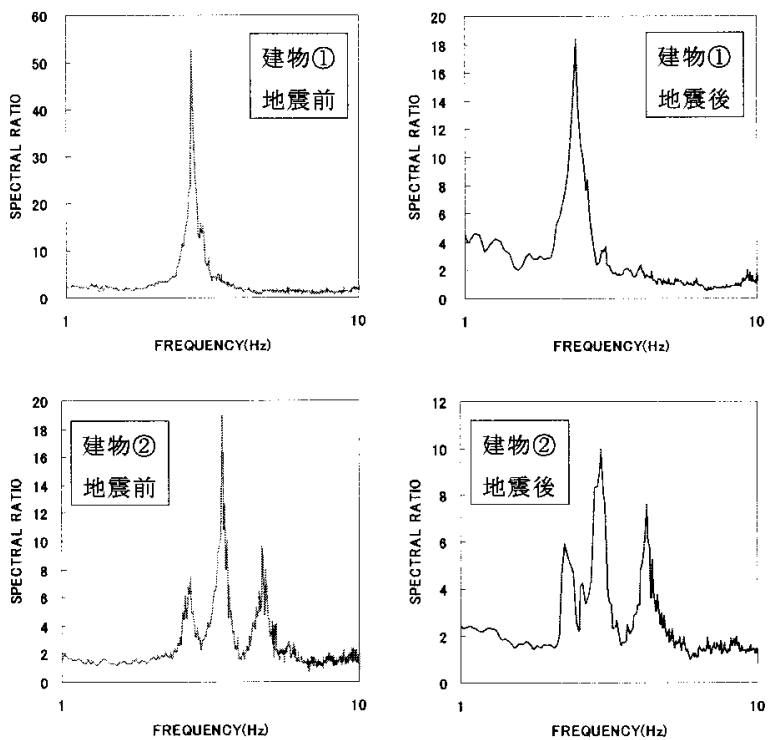

図 3 同建物の地震前のスペクトル比（左）と 地震後のスペクトル比（右）の例
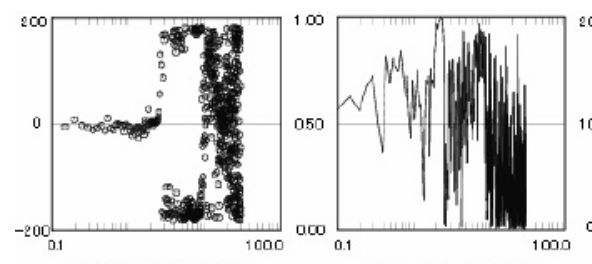

LOQ (FFEQUENOYOHZ))

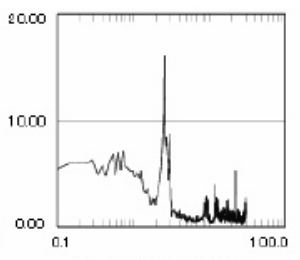

LOS (FREQUENOYOHZ)
図 4 同建物の伝達関数の位相（左）とコヒーレンス（中）と

$$
\text { フーリエスペクトル比（右）の例 }
$$

とも振動数判定の補助情報とした。図 3 に同一建物における地震前 後のフーリエスペクトル比の例、図 4 に伝達関数の位相とコヒーレ ンスの例を示す。

\section{4 地盤上あるいは最下階との比から求めた共振振動数}

図 5 ・図 6 に、建物最上階, 最下階, 周辺地盤上の 3 点で測定を 行った 45 棟（測定は長手方向と短手方向の水平 2 成分で行ってい るため、データ数は 90）の、最上階/最下階から得た共振振動数と 最上階/周辺地盤上から得た共振振動数を比較したグラフを示す。前 述した基準点を周辺地盤上にするか建物最下階にするかについて、 これらの図から、入力を周辺地盤上として得た共振振動数と、最下 階として得た共振振動数の差は小さく、例外はあるが平均で $6 \%$ 程 度と僅かであることが認められるため、今回の解析では誤差の範囲 内として同様に扱えるものとした。

\section{3. 地震前後の振動特性の比較}

\section{1 剛性低下率}

測定は各建物の水平 2 方向において行っているので、比較可能な データ数は 158 である。固有振動数は

$$
\omega=\sqrt{k / m}
$$

と表されるので、地震前後で建物質量に変化がないと仮定し、

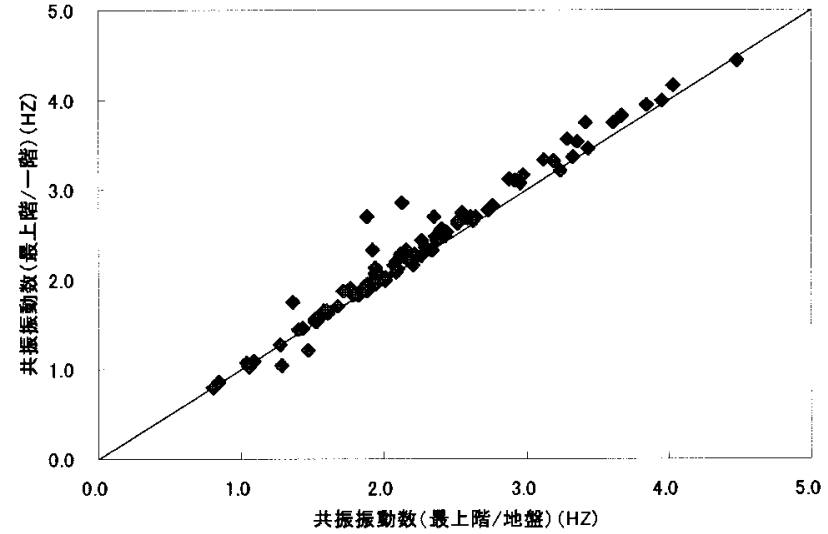

図 5 最上階/最下階から得た共振振動数と 最上階/地盤から得た共振振動数の比較

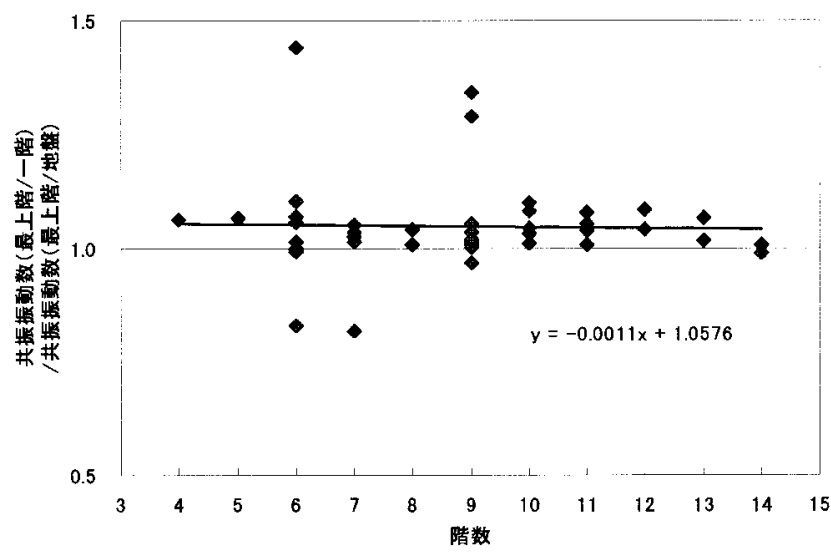

図 6 階数別の最上階最下階から得た共振振動数と 最上階/地盤から得た共振振動数の比

$\left(\frac{\text { 地震後の共振振動数 } \omega_{\text {after }}}{\text { 地震前の共振振動数 } \omega_{\text {before }}}\right)^{2}=$ 剛性低下率

として扱う。地震後のほうが地震前よりも剛性が大きくなっている 建物が数棟存在するが、これらは誤差の範囲内としてそのまま扱う こととした。ただし地震後の共振振動数が著しく増大している建物 については、建て替られたか、もしくは建物を誤認しているものと してデータから取り除いている。

図 7 に剛性低下率と地震前の共振振動数の関係を示す。図から、 共振振動数が低い建物のほうが、剛性がより大きく低下しているこ とが判る。しかし剛性低下率と地震前の共振振動数を各階の平均值 で除した偏差とを比較した図8からは、殆ど相関は見られないので、 図 7 の傾向は主として後述する建物の階数に因るものであり、「剛 性低下は相対的に脆弱な建物に多かった」とはいえない。

表 2 に立地区・階数別の平均剛性低下率を示す。全データの剛性 低下率の平均は 0.800 であり、立地区別では中央区が 0.751 と最も 剛性が低下しており、以下博多区，早良区，南区，城南区となって いる。同様に階数別では、剛性が大きく低下しているものから、7 $\sim 9$ 階建（0.765）、10〜 14 階建（0.774）、4〜6階建（0.859）とな っている。しかしながら、地震入力が相対的に大きかったと推測さ 


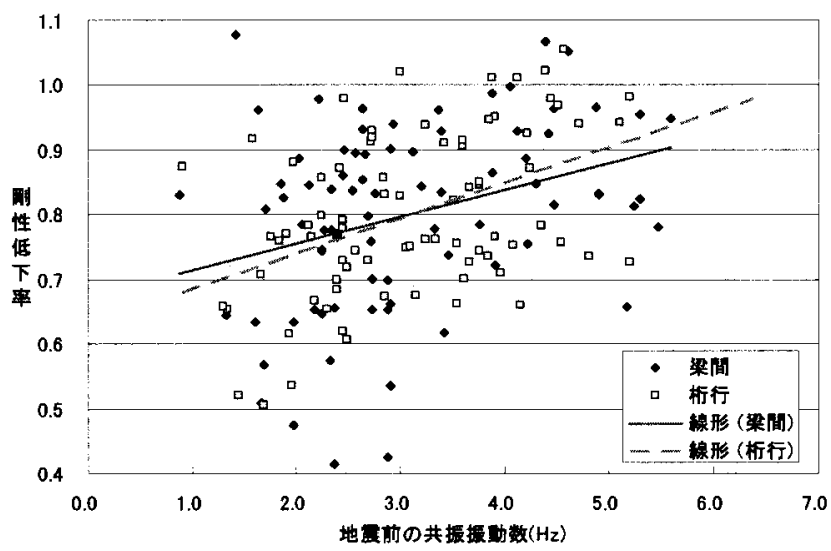

図 7 剛性低下率と地震前の共振振動数

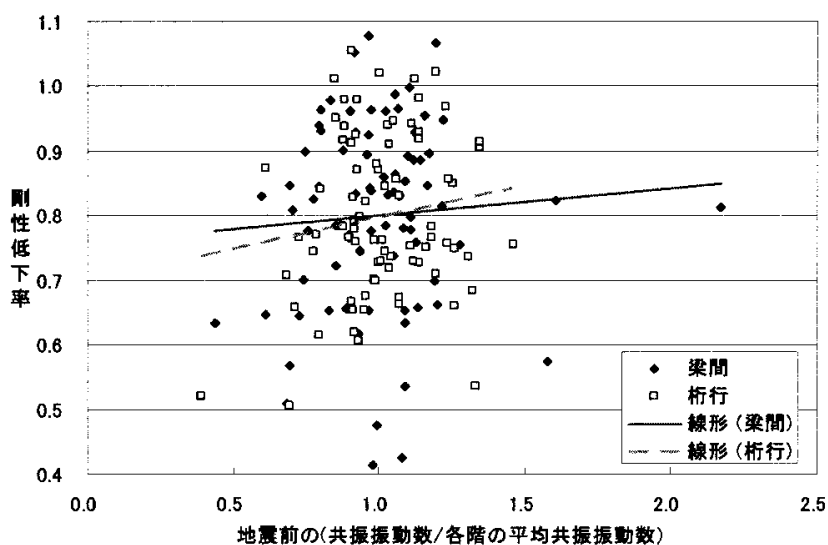

図 8 剛性低下率と地震前の共振振動数偏差

(=共振振動数 /各階の平均共振振動数)

表 2 立地区・階数別の平均剛性低下率（0内はデータ数）

\begin{tabular}{|c|c|c|c|c|}
\hline 区\階数 & $4 \sim 6$ & $7 \sim 9$ & $10 \sim 14$ & 全 \\
\hline 中央区 & $0.803(20)$ & $0.746(24)$ & $0.687(14)$ & $0.751(58)$ \\
\hline 博多区 & $0.888(4)$ & $0.772(14)$ & $0.687(32)$ & $0.804(50)$ \\
\hline 早良区 & $0.870(12)$ & $0.823(4)$ & $0.664(2)$ & $0.837(18)$ \\
\hline 南区 & $0.900(14)$ & $0.781(8)$ & $0.830(6)$ & $0.851(28)$ \\
\hline 娍南区 & $0.931(4)$ & $(0)$ & $(0)$ & $0.931(4)$ \\
\hline 全 & $0.859(54)$ & $0.765(50)$ & $0.774(54)$ & $0.800(158)$ \\
\hline
\end{tabular}

れる中央区，博多区，早良区では、10～14 階建の建物のほうが 7〜 9 階建の建物よりも $5 \sim 15 \%$ 程度大きく剛性が低下しており、階数 の多い建物から順に剛性が大きく低下しているといえる。

図 9 •表 3 に剛性低下率の階数分布、図 10 ・表 4 に剛性低下率の 立地区分布を示す。階数分布では、全体として $0.7 \sim 0.8$ でピークが 表れているが、4〜 6 階建の建物では 0.9 台で最大となっている。立 地区分布では、中央区が 0.7 台、博多区，南区が 0.8 台、その他の 区ではそれ以上のところで最大となっており、全体では 7 階建以上 の建物、中央区次いで博多区, 南区に立地する建物で剛性が大きく 低下していることが判る。

3. 2 剛性低下率と入力地震動レベルの比較

佐藤ら ${ }^{8}$ ) は、町丁目別の工学的基盤深さの情報と福岡市内で得ら れた強震観測記録に基づき、 1 次元地盤モデルを設定し、逆算工学

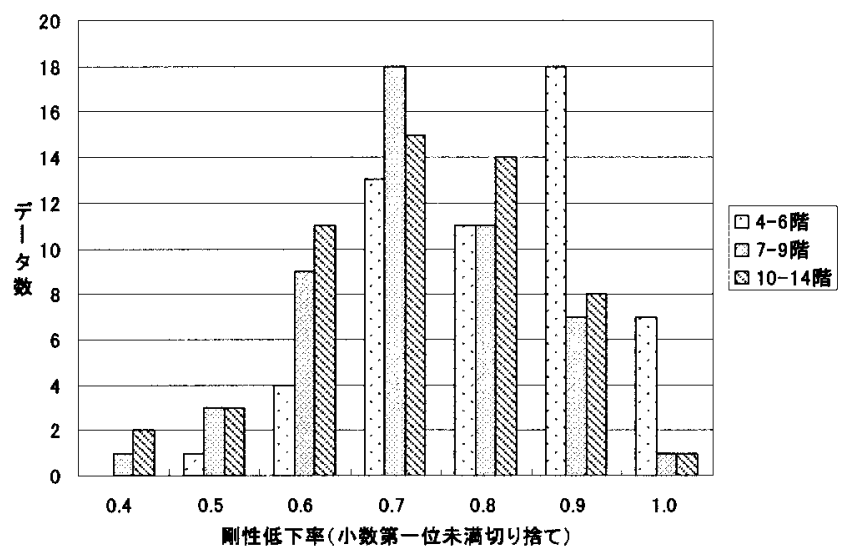

図 9 剛性低下率の階数分布

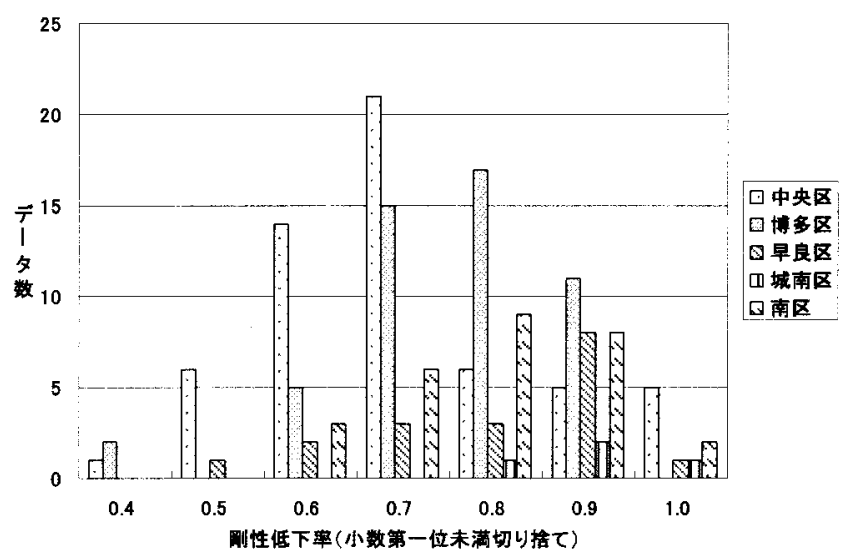

図 10 剛性低下率の立地区分布

表 3 剛性低下率の階数分布（值はデータ数）

\begin{tabular}{|c|c|c|c|c|}
\hline 㧩性低下率入階数 & $4 \sim 6$ & $7 \sim 9$ & $10 \sim 14$ & 計 \\
\hline 0.4 以上 0.5 未渵 & 0 & 1 & 2 & 3 \\
\hline 0.5 以上 0.6 未满 & 1 & 3 & 3 & 7 \\
\hline 0.6 以上 0.7 未满 & 4 & 9 & 11 & 24 \\
\hline 0.7 以上 0.8 末满 & 13 & 18 & 15 & 46 \\
\hline 0.8 以上 0.9 末満 & 11 & 11 & 14 & 36 \\
\hline 0.9 以上 1.0 末满 & 18 & 7 & 8 & 33 \\
\hline 1.0 以上 1.1 末満 & 7 & 1 & 1 & 9 \\
\hline 計 & 54 & 50 & 54 & 158 \\
\hline
\end{tabular}

表 4 剛性低下率の立地区分布（値はデータ数）

\begin{tabular}{|c|c|c|c|c|c|c|}
\hline 刜性呧下事】区 & 中央 & 博多 & 早良 & 南 & 城南 & 計 \\
\hline 0.4 以上 0.5 未满 & 1 & 2 & 0 & 0 & 0 & 3 \\
\hline 0.5 以上 0.6 末渵 & 6 & 0 & 1 & 0 & 0 & 7 \\
\hline 0.6 以上 0.7 末满 & 14 & 5 & 2 & 3 & 0 & 24 \\
\hline 0.7 以上 0.8 未满 & 21 & 15 & 3 & 6 & 0 & 45 \\
\hline 0.8 以上 0.9 未满 & 6 & 17 & 3 & 9 & 1 & 36 \\
\hline 0.9 以上 1.0 末满 & 5 & 11 & 8 & 8 & 2 & 34 \\
\hline 1.0 以上 1.1 末满 & 5 & 0 & 1 & 2 & 1 & 9 \\
\hline 計 & 58 & 50 & 18 & 28 & 4 & 158 \\
\hline
\end{tabular}



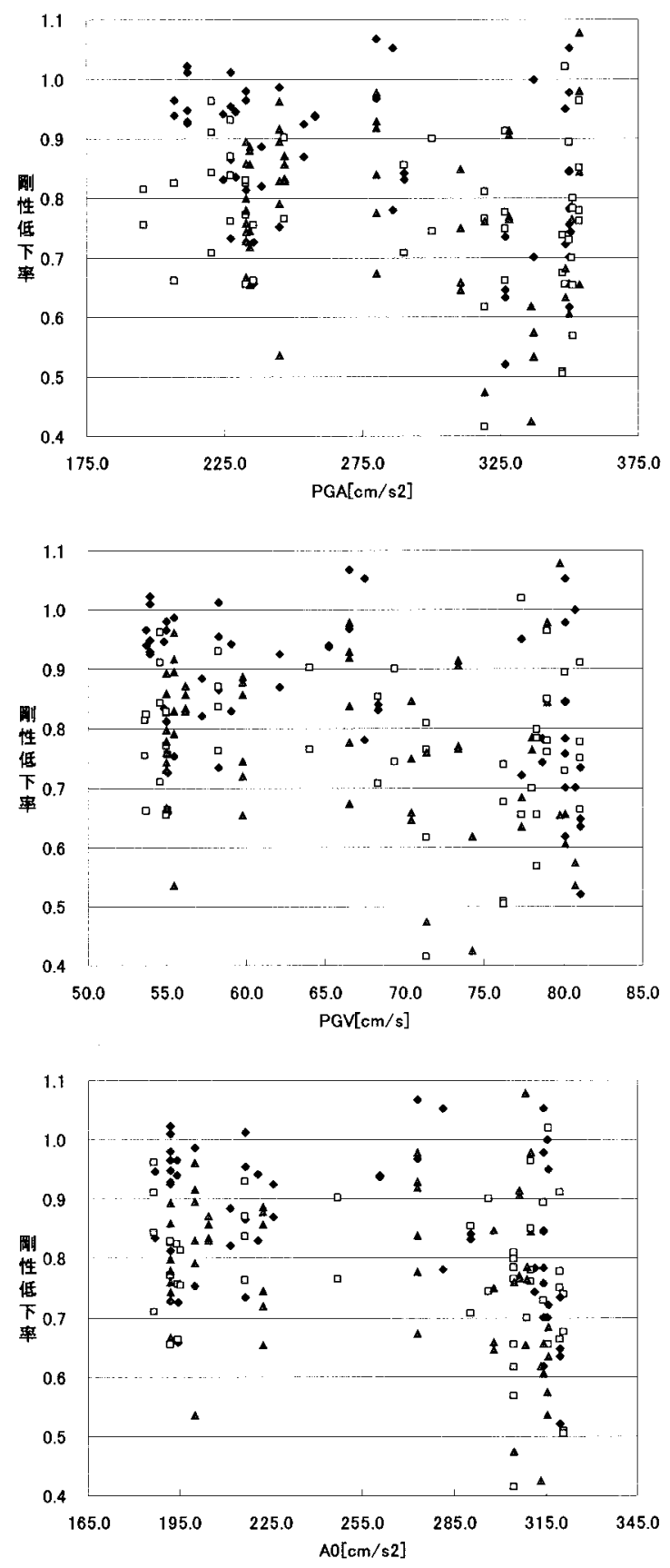

図 11 剛性低下率と入力地震動レベル

(上から PGA $\left.\left(\mathrm{cm} / \mathrm{s}^{2}\right), \mathrm{PGV}(\mathrm{cm} / \mathrm{s}), \mathrm{A} 0\left(\mathrm{~cm} / \mathrm{s}^{2}\right)\right)$

的基盤波を推定するとともに、観測波形の再現を行っている。再現 されたそれらの観測波形のうち、最大入力加速度 PGA, 最大入力速 度 $\mathrm{PGV}$, 計測震度を計算する際のフィルター後合成加速度 $\mathrm{A} 0$ を入 力の最大值指標（以下、入力地震動レベル）として剛性低下率と比 較した。ここで $\mathrm{A} 0$ を指標に加えているのは、増田ら 9)により $\mathrm{A} 0$ と 被害関数との相関が良いことが示されているためである。

図 11 に、 79 棟分 158 データの剛性低下率と入力地震動レベルの 関係を示す。また図 12 に、剛性低下率と最も対応の良かった PGA についてのみ、水平 2 方向のうち剛性低下の大きかった 1 方向のみ をプロットしたグラフを示す。全体として入力地震動レベルが大き くなるにつれて、剛性が低下していることが見て取れる。階数別に

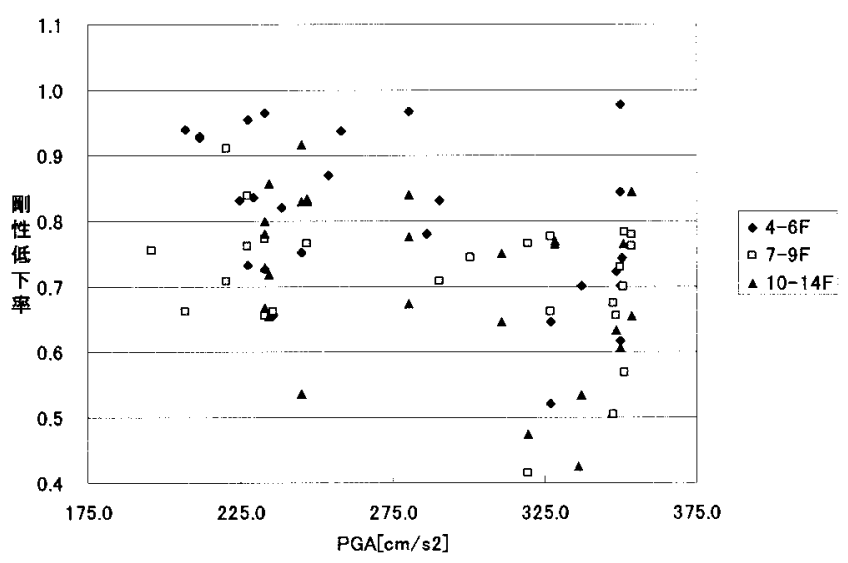

図 12 剛性低下率と PGA $\left(\mathrm{cm} / \mathrm{s}^{2}\right)$ （1建物の水平 2 方向のうち、 剛性低下率が小さい 1 方向のみプロット)

見ると、 $4 \sim 6$ 階建の建物のほうが 7 階建以上の建物よりも 1.0 に近 いところに分布していることが判る。また、入力地震動レベルが大 きくなるにつれて、剛性低下率の下限は低下していくが、上限は 1.0 に近く、あまり変化していないことが判る。このことは、建物の弾 性限界に大きなばらつきがあることを示唆している。水平 2 方向の うち剛性低下の大きい 1 方向のみで比較した図 12 からも図 11 と同 様の傾向が見られ、水平 2 方向で比較した場合と同様の結果が得ら れることが判る。

次に、入力地震動レベルを $5 つ$ 群 $\mathrm{I} \sim \mathrm{V}$ に分け $\left(\mathrm{A} 0\right.$ は $180 \mathrm{~cm} / \mathrm{s}^{2}$ から $30 \mathrm{~cm} / \mathrm{s}^{2}$ 毎, PGAは $190 \mathrm{~cm} / \mathrm{s}^{2}$ から $34 \mathrm{~cm} / \mathrm{s}^{2}$ 毎, PGVは $53 \mathrm{~cm} / \mathrm{s}$ から $5.8 \mathrm{~cm} / \mathrm{s}$ 毎)、それぞれの階数別平均剛性低下率、及び全階数 の平均剛性低下率と標準偏差を求めた。それらを図 13 に示す。ま た最も対応の良い結果が得られた PGA について、詳細を表 5 に示 す。全階数の平均值を見ると、A0 がIV 以下、PGA，PGV が III 以下 の地域の建物では、地震前の $80 \%$ 以上の剛性を保っているが、入力 地震動レベルがそれらより大きな地域では、地震前の剛性の 70〜 $75 \%$ 程度へと急激に低下している。階数別に見ると、4〜6階建の建 物は常に全階数の平均值よりも大きな剛性を保っているが、 7 階建 て以上の建物では概ね全階数の平均值程度か、それ以下となってい る。また、全階数と同様に 4 6 階建の建物においても、A0 がIV以 下、PGA，PGVが而以下の地域では地震前の 85〜 95\%程度の剛性 を保っているが、A0，PGA，PGV ともにVの地域では全て 0.779 まで低下しており、7 階建以上の值に急激に近づいている。7 階建 以上の建物においても、A0がIV以下、PGA，PGVがIII以下の地域 では地震前の $80 \%$ 前後の剛性を保っているが、入力地震動レベルが それらより大きな地域では地震前の $65 〜 75 \%$ の剛性へと急激に低 下している。さらに、A0, PGA, PGV ともにIV以下の地域では、 階数によって平均剛性低下率にばらつきがあるが、Vの地域では階 数に拘らず 0.75 程度に収束しているように見える。全階数の標準偏 差について見ると、入力地震動レベルが大きくなるにつれて剛性低 下率の標準偏差も大きくなることが判り、図 11 と同様に、これら のグラフからも建物の弾性限界に大きなばらつきがあることが示唆 される。

表 6 に立地区別の平均剛性低下率 (3.1節の表 2) と立地区別平均 入力地震動レベル（立地町丁目のみの平均值）を示す。図 13 には 


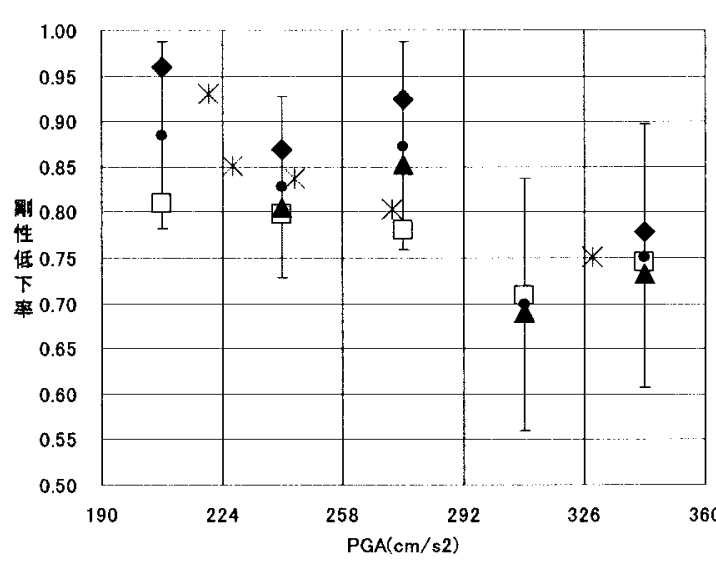

$\hookrightarrow 4-6 \mathrm{~F}$

$\square 7-9 F$

A 10-14

- 全階数

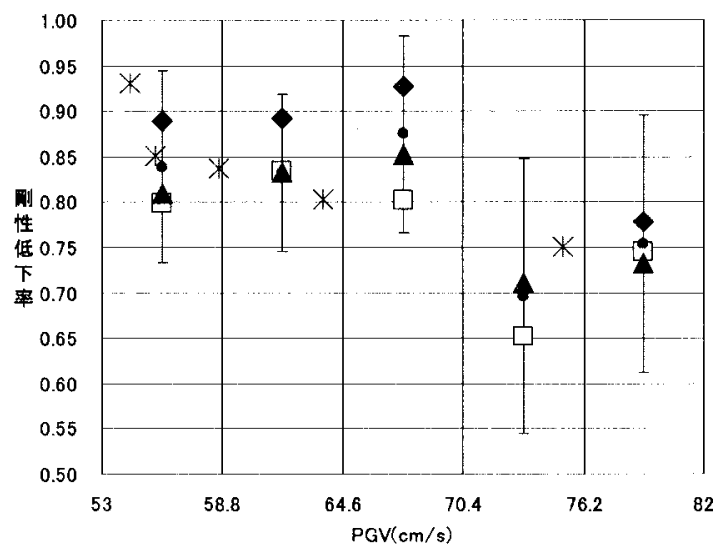

$4-6 \mathrm{~F}$ $4-6 \mathrm{~F}$
$7-9 \mathrm{~F}$ A $10-14 \mathrm{~F}$ 全階数

米区平均

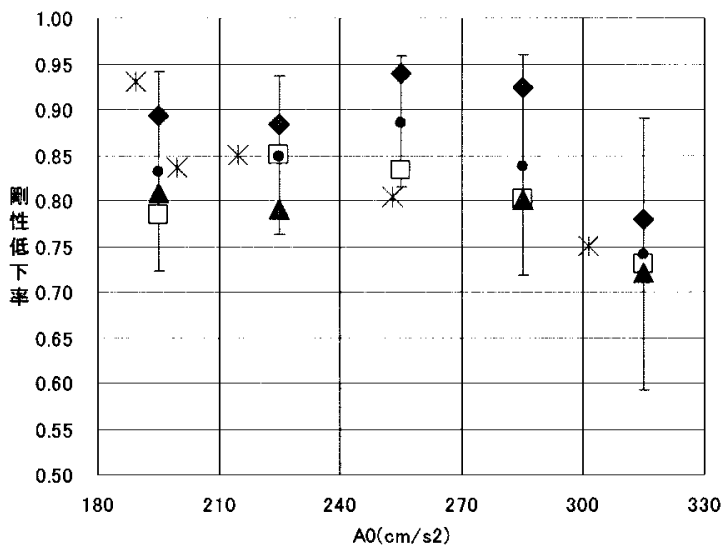

$4-6 \mathrm{~F}$

$10-14 \mathrm{~F}$

$10-14 \mathrm{~F}$

全階数

図 $13 \mathrm{PGA}\left(\mathrm{cm} / \mathrm{s}^{2}\right), \mathrm{PGV}(\mathrm{cm} / \mathrm{s}), \mathrm{A} 0\left(\mathrm{~cm} / \mathrm{s}^{2}\right)$ 值別の 平均剛性低下率（Iは全階数の標準偏差）

*でそれを示した。それらの值は概ね全体の入力地震動レベルと岡 性低下の関係に合っており、3.1 節で岡性が大きく低下した建物が 多く存在していた中央区は、剛性が急激に低下している地域にある ことなどが確認できる。

増田ら 9)により、兵庫県南部地震の被害関数を用いて、被害関数 に用いる適切な入力指標の検討がされており、そこでは PGA, PGV よりも A0 のほうが被害関数と良く対応するという結果が得られて いる。そこで今回も 3 種類の強度指標で比較したが、今回のような 軽微な被害の場合には、各指標に大差はなく、その中では PGA を 指標とした場合に最も良い相関が見られた。
表 $5 \mathrm{PGA}\left(\mathrm{cm} / \mathrm{s}^{2}\right)$ 值別の平均剛性低下率 $(0$ 内はデータ数 $)$

\begin{tabular}{|c|c|c|c|c|}
\hline $\mathrm{PGA}\left(\mathrm{cm} / \mathrm{s}^{2}\right) \backslash$ 階数 & $4 \sim 6$ & $7 \sim 9$ & $10 \sim 14$ & 全 \\
\hline $\mathrm{I}(190$ 以上 224 未満 $)$ & $0.960(8)$ & $0.810(8)$ & $(0)$ & $0.885(16)$ \\
\hline II (224 以上 258 未满) & $0.869(22)$ & $0.797(12)$ & $0.805(24)$ & $0.828(58)$ \\
\hline III (258 以上 292 未満) & $0.924(6)$ & $0.781(2)$ & $0.853(6)$ & $0.873(14)$ \\
\hline $\mathrm{IV}(292$ 以上 326 未満 $)$ & $(0)$ & $0.708(6)$ & $0.690(6)$ & $0.699(12)$ \\
\hline $\mathrm{V}(326$ 以上 360 未满 $)$ & $0.779(18)$ & $0.745(22)$ & $0.734(18)$ & $0.752(58)$ \\
\hline 全 & $0.859(54)$ & $0.765(50)$ & $0.774(54)$ & $0.800(158)$ \\
\hline
\end{tabular}

表 6 立地区別の平均剛性低下率（○内はデー夕数）(表 2)と 立地町丁目の区毎の平均入力地震動レベル

$\left(\mathrm{AO}\left(\mathrm{cm} / \mathrm{s}^{2}\right)\right.$, PGA $\left(\mathrm{cm} / \mathrm{s}^{2}\right)$, PGV $\left.(\mathrm{cm} / \mathrm{s})\right)$

\begin{tabular}{|c|c|c|c|c|}
\hline 立地区 & $\mathrm{A} 0$ & $\mathrm{PGA}$ & $\mathrm{PGV}$ & 平均剛性低下率 \\
\hline 中央 & 301.2 & 328.1 & 75.2 & $0.751(58)$ \\
\hline 博多 & 252.8 & 271.8 & 63.7 & $0.804(50)$ \\
\hline 早良 & 199.6 & 244.4 & 58.7 & $0.837(18)$ \\
\hline 南 & 214.7 & 226.8 & 55.6 & $0.851(28)$ \\
\hline 城南 & 189.5 & 220.3 & 54.4 & $0.931(4)$ \\
\hline
\end{tabular}

\section{3 剛性低下率と被害レベルの比較}

日本建築学会福岡県西方沖地震災害調查委員会 ${ }^{10}$ ) は、福岡市内の 特定地域において、建物およびブロック塀等の被害調查を行ってい る。その調查結果のうち、微動測定の対象地域と重なる赤坂 $1 丁$ 目、 大名 1,2 丁目、今泉 2 丁目の被害調査結果を用い、剛性低下率と 比較した。

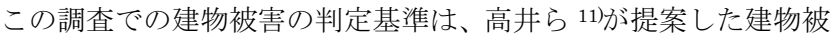
災度区分によるものとしており、 $\mathrm{RC}$ 造と $\mathrm{SRC}$ 造については「鉄筋 コンクリート造建物の破壊パターン ${ }^{11)}$ 」に従って、目視で判定され ている。被害レベルは D0（無被害）～D6（全壊）で表され、数值 が大きくなるにつれて、被害も大きくなる。

微動測定の対象建物のうち、被害調查地域と重なる地域に立地寸 る建物は 11 棟存在する。この 11 棟について、剛性低下率と被害レ ベルとの比較を行う。表 7 に対象建物の概要と被害レベル及び岡性 低下率を、図 14 に剛性低下率と被害レベルとの関係を示す。建物 の被害レベルの内訳は D0（無被害）が 8 棟、D1，D2（ともに一 部破損）がそれぞれ 2 棟，1棟となっている。図 14 から、一部破 損が見られる建物では、無被害の建物よりも剛性が低下しているこ とが明らかである。対象建物の被害レベルが偏っており、データ数 は少ないが、剛性低下率と目視による被害調査と相関があることは 明らかであり、この相関関係から大きく外れる剛性低下を示してい る建物では、目視困難な部位に損傷を受けている可能性がある。

\section{4.まとめと考察}

地震前に行われていた福岡市内の多数の建物の常時微動の測定結 果、及び地震後に同一建物に対して我々が実施した微動記録を用い て、2005 年福岡県西方沖地震 (M7.0)の前後における振動特性の変化 を把握した。さらにその変化の程度と入力地震動レベルおよび地区 別の建物損傷度との比較を行った。以下に、それらの解析結果から 得られた結論を示す。

1）共振振動数の平均值からの偏差と剛性低下率の間には殆ど相関 はなく、図 7 に示された地震前の共振振動数と剛性低下率の間の 


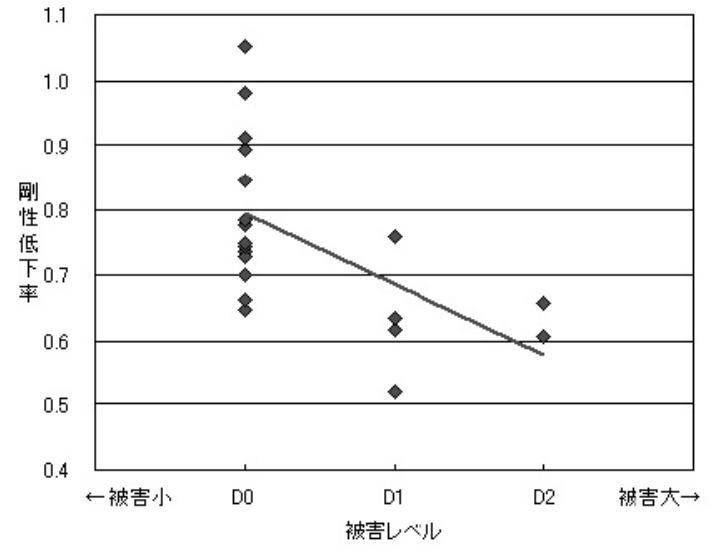

図 14 剛性低下率と被害レベル

表 7 建物概要と被害レベル・剛性低下率

\begin{tabular}{|c|c|c|c|c|c|}
\hline \multirow{2}{*}{$\begin{array}{l}\text { 建物 } \\
\text { 番号 }\end{array}$} & \multirow[t]{2}{*}{ 䧄数 } & \multirow[t]{2}{*}{ 立地 } & \multirow{2}{*}{$\begin{array}{l}\text { 被害 } \\
\text { レベル }\end{array}$} & \multicolumn{2}{|c|}{ 㣚性纸下率 } \\
\hline & & & & 短辺方向 & 艮辺方向 \\
\hline 125 & 8 & 大名 2 & D0 & 0.777 & 0.912 \\
\hline 126 & 6 & 大名 2 & D0 & 0.647 & 0.736 \\
\hline 132 & 9 & 大名 1 & Do & 0.893 & 0.729 \\
\hline 133 & 4 & 大名 1 & Do & 1.053 & 0.979 \\
\hline 135 & 6 & 大名 1 & D0 & 0.701 & 0.784 \\
\hline 136 & 10 & 今泉 2 & D2 & 0.657 & 0.606 \\
\hline 137 & 6 & 今泉 2 & D1 & 0.618 & 0.758 \\
\hline 138 & 6 & 今泉 2 & D0 & 0.847 & 0.846 \\
\hline 252 & 6 & 赤坂 1 & D0 & 0.785 & 0.744 \\
\hline 253 & 6 & 大名 2 & D1 & 0.635 & 0.521 \\
\hline 255 & 9 & 大名 2 & Do & 0.662 & 0.750 \\
\hline
\end{tabular}

相関は、建物の階数に因るものであると考えられる。全体として、 階数の多い建物や入力地震動の大きかった区に建つ建物で、剛性 が大きく低下していることが確認された。

2）全体的に、入力地震動レベルが大きくなるにつれて、剛性が低下 する傾向が認められた。その傾向は建物の階数が多いほど顕著で あった。また、入力地震動レベルが大きくなるにつれて剛性低下 率の下限は低下していくが、上限は 1.0 に近いままであり、建物 の弾性限界に大きなばらつきがあることが示唆された。水平 2 方 向のうち、剛性低下の大きい 1 方向についてのみ比較した場合も、 同様の結果が得られた。

3) PGA，PGV，A0の各指標とも、剛性低下率との対応に大差は見 られなかったが、その中では PGA が最も良く対応している。こ れは軽微な被害が PGA と最もよい相関があることから見ても妥 当だと考えられる。

4）一部破損が見られる建物では、無被害の建物よりも剛性が低下し ていた。剛性低下率と目視による被害調查と相関があることが確 認され、この相関関係から大きく外れる剛性低下を示している建 物では、目視困難な部位に損傷を受けている恐れがある。

以上の結果から、地震前後における建物の振動特性の変化と、入 力地震動レベル・被害レベルとの間には相関があることが認められ た。固有振動数の低下は非構造部材の剛性低下に起因するものも多 いと考えられるが、それらを超えて大きな剛性低下を示した場合に
は、目視では確認できなかった部位に重大な損傷を受けている可能 性があり、詳細調查をするか否かの判断には有効であると考えられ る。逆に、振動数にほとんど変化がないということは、全断面が弾 性範囲内の変形に留まったことを示唆しており、安心して使用し続 けることができるといえる。

今回の調查結果から、 RC 造建物の微動から得られる共振振動数 は、入力レベルが主要構造物の部分的破壊に至らないような震度 5 強〜 6 弱レベルのものであっても、平均的な構造物ではかなり明瞭 に低下をきたすことが判った。これが主要構造部材のコンクリート のびひわれの拡大等によるものなのか、非構造部材の剛性低下によ るものなのかは今回の調査結果だけからは判断がつかないが、大地 震時の構造物の挙動を予測する上でそのモデル構築が非常に重要で あり、剛性低下のモデル化も含め今後検討していきたい。

\section{謝辞}

常時微動測定の実施にあたり、川瀬・清家研究室のメンバー及び 建物所有者・管理者に全面的に御協力頂きました。また 1995 年の 振動特性の解析には、豊田工業高等専門学校の今岡克也教授に御助 言及び御協力頂きました。ここに深く感謝の意を表します。

参考文献

1）横田治彦, 田村和夫, 斎藤知生, 林康裕, 高橋郁夫, 角陸純一：1995 年 兵庫県南部地震における S R C 造被災建物の動特性（その 1 : 被災状況 と地盤・建物の卓越振動数), 日本建築学会大会学術講演梗概集（北海 道）構造 II，B-2, pp.71-72，1995.8

2）沢井布兆，横山浩明，石田潤一郎，藤田睦，松谷輝雄，小堀隆治：兵庫 県南部地震における高見フローラル超高層 R C 造集合住宅の検証（2） 地震観測の概要および観測記録 I, 日本建築学会大会学術講演梗概集 （北海道）構造 II ， B-2, pp.431-432, 1995.8

3）此上典文, 野畑有秀, 安井譲: 兵庫県南部地震における鉄骨造高層建物 の地震応答, 日本建築学会大会学術講演梗概集 (北海道) 構造 II, B-2, pp.439-440, 1995.8

4）高崎芳夫, 平澤光春, 鈴木敏夫 : 高層建物での兵庫県南部地震の観測結 果と固有周期の変動，日本建築学会大会学術講演梗概集（北海道）構造 II , B-2, pp.441-442, 1995.8

5）松岡昌志，翠川三郎，赤木久眞，奥田賢持，土肥博，二宮利文：兵庫県 南部地震における N T T 建物の地震記録について（その４）本震前後に おける神戸駅前ビルの振動特性の変化、日本建築学会大会学術講演梗概 集（近畿）構造II ，B-2，pp.549-550，1996.9

6) 阿部良洋, 守研二, 小川淳二, 星道夫 : 宮城県沖地震の前後に於ける常 時微動の測定からみた建物の剛性低下について（その1-3），日本建築 学会大会学術講演梗概集 (関東) 構造系 54, pp.437-442，1979.9

7）今岡克也, 清家規, 大西貴史, 多賀直恒 : 微動計測に基づく表層地盤を 考慮した建物の地震応答評価に関する研究, 日本建築学会構造系論文集, 第 490 号，pp.101-110，1996.12

8）佐藤智美，川瀬博，松島信一：2005 年福岡県西方沖の地震での福岡市 中心部での強震記録と表層地盤増幅その 2 逆算工学的基盤波と表層 1 次元モデルによる再現波, 日本建築学会大会学術講演梗概集 (近畿) 構 造系 B-2，pp.119-120，2005.9

9）増田有周，長戸健一郎，川瀬博： $\mathrm{RC}$ 造建物の地震応答解析結果に基つ く被害関数構築に関する研究, 日本建築学会構造系論文集, 第 558 号, pp.101-107, 2002.8

10）日本建築学会：2005 年福岡県西方沖地震災害調查報告, 丸善, 2005.9

11）高井伸雄，岡田成幸：地震被害調査のための鉄筋コンクリート造建物の 破壊パターン分類, 日本建築学会構造系論文集, 第 549号, pp.67-74, 2001.11 